\title{
WILLIAM JOHN RITCHIE SIMPSON (1855-1931): PUBLIC HEALTH AND TROPICAL MEDICINE
}

\author{
by
}

\author{
R. A. BAKER* AND R. A. BAYLISS ${ }^{\dagger}$
}

Simpson's long working life covered a wide field. The pioneering nature of his work in public health and tropical hygiene involved a number of appointments at home and abroad. He worked in Aberdeen as Medical Officer of Health, in India as Health Officer for Calcutta, and in London he taught as Professor of Hygiene at King's College, becoming one of the founders of the London School of Hygiene and Tropical Medicine. The knowledge and experience gained was useful later when he travelled widely abroad as an adviser. He made tropical hygiene his own speciality and became an authority in the British Empire.

William Simpson was born in Glasgow on 27 April 1855. Details of his early life are scanty. ${ }^{1}$ His parents died when he was young, and he was at school in Jersey and a medical student in Aberdeen. The staff at the Medical School included some notable men, including "Barron" William Pirrie, who combined the chair of surgery with a flourishing practice and an arduous daily routine of early-morning writing. ${ }^{2}$ Simpson graduated in 1876 with "honourable distinction", ${ }^{3}$ but the next few years are not well documented. There is evidence to suggest that he may have been a medical assistant in a practice in Huddersfield, ${ }^{4}$ and around 1878 was on the staff of Haydock Lodge Retreat near Newton-le-Willows. ${ }^{5}$

Simpson then moved to Kent, where he was Medical Officer for St Mary's District of Dover Poor Law Union and public vaccinator, as well as holding an appointment at a convalescent home. ${ }^{6}$ With an Aberdeen MD and the Cambridge certificate in Sanitary Science (later DPH) he applied for the vacant post of Medical Officer of Health for Aberdeen.

Francis Ogston, the City's "first significant M.O.H." had combined his public office from 1862 with an academic chair. ${ }^{7}$ His pluralism was the subject of a forthright comment by Edwin Chadwick in 1877: "Full five hundred and fifty lives a year are sacrificed even in Aberdeen, by its existing insanitary conditions. I find that a public health officer is appointed with a salary of $£ 50$ a year. He has, I am informed, $£ 50$ more

*R. A. Baker, MSc, PhD, FIBiol., Centre for Combined Studies, University of Leeds.

${ }^{\dagger}$ R. A. Bayliss, BSc, MA, FRSA, Foresterhill College, Aberdeen.

${ }^{1}$ M. Watson, 'W. J. R. Simpson', Dictionary of National Biography 1931-1940, London, Oxford University Press, 1949, pp. 812-813.

2 'The late Professor Pirrie', Edinb. med. J., 1883, 28: 662-668.

${ }^{3} \mathrm{~W}$. Johnston, Roll of the graduates of the University of Aberdeen, Aberdeen University Press, 1906, pp. 490,645 .

${ }^{4}$ Correspondence with Kirklees Library, Huddersfield.

${ }^{5}$ Medical Directory, 1881, p. 1433.

${ }^{6}$ Ibid., pp. 702, 844.

${ }^{7}$ I. A.G. MacQueen, A hundred years of health workers in Aberdeen. Report by the Medical Officer of Health for 1962, Aberdeen, 1963, pp. 154-158. 


\section{William John Ritchie Simpson (1855-1931)}

for the performance of certain minor duties attached to the police service. But here I find that $£ 50$ a year is deemed to suffice for the preventive service of a learned professional man, a professor of medical jurisprudence, as officer to see to the prevention of the disease of some hundred thousand of population of this important city." 8

Simpson's appointment in June 1881 combined five duties, including superintending the newly-opened "epidemic" hospital, at an annual salary of $£ 300 .{ }^{9}$ Simpson's first report set a pattern of straightforward comment and included his warning about the habit of underestimating the dangers of whooping-cough. ${ }^{10}$ In the next report, he reflected on the purpose of his work. "The object of all sanitary work is that the child, who dies now at five years of age or under, should, by proper care, be prevented from so doing and thus guarded from the dangers that beset it, live a useful, or, as it may be, a useless life, and then die at a sensible age - an old man or an old woman."11

Simpson's duties had many aspects, which are reflected in his frequent reports. The perennial problem of relations with adjacent local authorities was shown by his comment in February 1882 that a fishing community across the River Dee not only supplied its larger neighbour with fish but also with scarlet fever, measles, and typhoid. "It is an excellent nursery ground for all the Zymotics; each Zymotic takes its turn, flourishing in rank luxuriance unmolested, until, having done all the mischief it can, it is, for a time, replaced by another."12

The longest account of Simpson's ideas is in an address to the Aberdeen Philosophical Society on 25 April $1882 .{ }^{13}$ On the housing problems of central and dockside Aberdeen he commented: "It can scarcely be supposed that people in these Courts will ever acquire habits of cleanliness surrounded by everything that leads in the opposite direction. Disease is no respector of rank ... no one is safe even in the better class houses. One section of society is intimately connected with the other sections, however far apart they may appear on the social scale, and whatever affects the one quickly affects the other." Simpson concluded by saying that "sanitary science includes, and tries to rectify, everything that leads to make injurious, the air, food, or drink, which are the necessities of a healthy life."

In Simpson's regular, full and informative reports, there was shrewd advice, for example, about isolation of patients, a tribute to the successful "pegging away of the sanitary inspectors", ${ }^{14}$ a plea for better abattoirs, and the cleaning of milk containers, grim accounts of extreme deprivation and overcrowding, and the "detection" work of tracing the source of diseases, amongst many other topics.

${ }^{8}$ E. Chadwick, Local sanitary organisation: the Medical Officer of Health, Congress of the Association for the Promotion of Social Science, Aberdeen, 1877.

${ }^{9}$ Medical Officer of Health. Town Council of Aberdeen Police Department. Minutes and Reports of Committees 1881, Aberdeen City Archives. (Hereinafter called ATC minutes.)

${ }^{10}$ Report of the MOH. ATC Minutes, 6 September 1881.

11 Ibid., 1 October 1881.

12 Ibid., 10 February 1882.

${ }^{13}$ W. J. R. Simpson, 'Health history of Aberdeen during the past quarter of a century', Trans Aberdeen Philosoph. Society, 1884, 1: 165-184. The paper contains much statistical information, mainly in graphical form. It should be noted that Simpson frequently used the first two Christian-name initials in publications. the full initials are used in this paper. 1884

${ }^{14}$ W. J. R. Simpson, Report on the state of public health and other sanitary work performed in 1883, Aberdeen, 


\section{R. A. Baker and R. A. Bayliss}

MacQueen has speculated on the reasons for Simpson's move from Aberdeen, suggesting hostility of those opposed to a full-time $\mathrm{MOH}$, and perhaps friction with colleagues. ${ }^{15}$ In January 1886, a new inspectorship of unwholesome food was created in Aberdeen. Simpson's salary, which had been raised during his stay in the city, was reduced, and in February he resigned. His letter of resignation made a polite comment on the help of councillors in duties "often of a delicate and difficult nature". ${ }^{16}$ At the farewell presentation to him of a gold watch, Dr Robert Beveridge, a council supporter of Simpson's work, commented on some of his colleagues. "They entertained apparently-at least to judge from their actions that was the case-to a very great extent that silly jealousy of medical men and medical opinions which they found so prevalent in ill-informed or ignorant individuals - a jealousy which, as they all knew, yielded from time to time to an almost superstitious reliance upon the doctor's power when danger came home to the individuals themselves in the form of serious illness. The Town Council had to undergo a considerable process of education before it came to understand ... that it was necessary to do anything and ... that anything could be done." Beveridge considered that Simpson had "discharged his duties with a quiet firmness, even when he was treading on people's toes". ${ }^{17}$

Simpson's career was to change dramatically when he was appointed Health Officer for Calcutta. Poverty, famine, over-population, and disease were part of the life of India in the second half of the nineteenth century. A very large proportion of India's population was miserably poor, and famine or increased food scarcity was immediately followed by an increased sickness and mortality. ${ }^{18}$ There were constant epidemics of plague and cholera, but no proper sanitary service existed. The recommendations of a Royal Commission on Health in India in 1859, the first modern survey of the situation, were acted upon only after epidemics had taken a heavy toll on life. In 1880, the military medical administration was unified and separated from the civil, the latter being reorganized and placed under the control of provincial governments. These local bodies founded and supported hospitals and employed medical and other personnel.

The population of the Hooghly district of Calcutta was halved between the late 1850 s and the late $1870 \mathrm{~s}^{19}$ due to epidemics of malaria and bubonic plague. The death rate in the mid-nineteenth century was 45 per 1,000 population and the expectation of life 20/25 years. An outbreak of plague in Bombay in 1896 spread rapidly to other parts of India. An eye-witness account of this outbreak prompted Simpson's comment: "The wholesome influence of a good water supply seems to have been generally impressed on the native mind but every departure from his customary habits in other respects is met with dislike and if it involves the least extra trouble with hostility, which makes itself felt in municipal affairs." 20

${ }^{15}$ MacQueen, op. cit., note 7 above, pp. 158-159.

${ }^{16}$ Minutes of the Town Council of Aberdeen 1885-86, 15 February 1886, para. 19, Aberdeen, 1887.

${ }_{17}^{17}$ Testimonial to Dr Simpson, Aberdeen Journal, 18 March 1886, p. 7.

18 D. Kumar (editor), The Cambridge economic history of India. 2: 1757-1970, Cambridge University Press, 1983, pp. 463-532.

19 Ibid., p. 480

20 'The plague in Bombay', Lancet, 1897, i: 132. 
In the sixteen years from the plague outbreak of 1896 , some eight million deaths had occurred from the disease and by 1919 this figure increased to ten million. ${ }^{21}$ Deaths due to the disease were, however, impossible to estimate accurately and were often understated because of, for example, the fear of quarantine, and were frequently concealed or reported under another name.

The first Health Officer for Calcutta had been appointed in 1864, and Simpson's own appointment owed something to Sir George Buchanan's influence. In the 1880s, Calcutta was the winter capital of British India, an overcrowded, industrial, commercial and seaport city of over 600,000 people with well-established medical institutions including the university and Medical Society, whose various medical personnel included the official Indian Medical Service and some of the unqualified, as the Indian Medical Gazette put it, "almost defying classification". 22

Simpson's work may be traced in the numerous reports that were published as the India Office blue books under the title of 'Sanitary Measures in India'. The responsibilities of health officers in Calcutta were complex and it is clear that health was not exempted from what Lord Curzon described as "the bureaucratic daily dance, stately, solemn, sure and slow". ${ }^{23}$

Simpson's first report for 1886 included a list of projects needing attention. A following extract illustrates the problems he faced: "A well with water hardly better than sewage, drains with deposits in them emitting offensive gases, filth both inside compound and surrounding the hut, overcrowding of huts and overcrowding of people in the huts." 24

Simpson noted the inadequate registration of deaths and inaccurate statistics, which he referred to in his first quarterly report as "Like the hands of a clock whose machinery is defective, what they indicate at any given time cannot be depended upon as being correct." 25

However, some progress was being made and under his advice additional staff had been appointed. "And something like an organized attempt was being made to remedy a few of the extremely insanitary conditions in the town, but now, after six months work, the whole organization has been broken up and dismissed on the grounds of economy ... . surely this is economy ill directed." 26

The Commissioner's own comment on these events claimed that the staff had only been temporarily employed and it was never intended that they should be retained for the registration of sanitary statistics. "The statement appears to convey a wrong impression of facts-the impression should not gain ground that the new Health Officer has been illiberally treated in the matter of establishment .... Dr. Simpson is in error in assuming that in any of these particulars there has been retrogression on the

${ }^{21}$ W. J. R. Simpson, 'Some considerations of preventable disease', ibid, 1919, ii: 821.

${ }^{22}$ Editorial, 'Medical practice in Calcutta', Ind. med. Gaz., 1882, 17: 213-217.

${ }^{23}$ S. Wolpert, A new history of India, 2nd ed., New York, Oxford University Press, 1982.

${ }^{24}$ Administration Report of the Commissioners of Calcutta for 1886-1887, Appendix B, p. 15, British Library, India Records, V/24/2873.

${ }^{25}$ Municipal Health Officers' Quarterly Reports for Calcutta 1876-1895, Quarterly Report 19 July 1886, p. 3, British Library, India Records, V/25/840/2.

${ }^{26}$ Administration Report of the Commissioners of Calcutta for 1886-1887, Appendix B, p. 29, British Library, India Records, V/24/2873. 


\section{R. A. Baker and R. A. Bayliss}

part of the Corporation."27 The report for 1888 was commented on in the Lancet: "Dr. Simpson is far from being satisfied with the system of drainage in Calcutta because it seems to be the impression that drainage mainly consists in laying down a large number of pipes irrespective of a consideration of the nature of the locality which may be densely crowded with buildings constructed on most irregular lines ... rendering effective drainage almost an impossibility." 28

From Simpson's last report it is clear that the general state of health in Calcutta was still very unsatisfactory, the death rate in 1896 being the highest for the previous thirty years with 2,090 deaths from cholera. He was still urging the necessity for building laws and a proper drainage system for Calcutta.

Simpson was an active member of the Calcutta Microscopical Society and editor for several years of the Indian Medical Gazette. The journal, first published in 1866, still aimed to be a "monthly record of Medicine, Surgery, Obstetrics, Hygiene and Jurisprudence both Indian and European". From 1871 to 1892, Surgeon Major K. McLeod, Professor of Surgery at the Medical College, Calcutta, was editor, to be joined in 1889 by Simpson, who became sole editor between 1892 and his departure from India in 1897. Both McLeod and Simpson wrote regularly in the journal, and more attention was devoted to public health under Simpson's influence. Other contributors included Ronald Ross, Waldemar Haffkine, and members of the medical services of Britain, Bengal, Madras, and Bombay. Current medical topics in the 1880s and 1890 s included cholera, plague, vaccination, malaria and other parasitic diseases, as well as sanitary matters such as water supplies, pollution, and sewage disposal.

Simpson left India in September 1897 in failing health. "Never of robust constitution and frequently suffering from ill health, he was, nevertheless, associated with every forward movement in medicine and hygiene in Calcutta .... in fact he was a man far in advance of his time. Neither the man in the street nor many of the City Fathers could appreciate the value of a Scientific Health Officer" ${ }^{29}$ His achievements were listed as "the reduction of food contamination, the establishment of a municipal laboratory, garbage incineration, better drainage, and an attack on the hitherto impregnable fortress of vested interests connected with the growth of the metropolis without adequate building regulations". ${ }^{30}$ Apart from the administrative work for the advancement of sanitation, much was accomplished by his investigation into the causes and mode of spread of cholera, and the fact that Haffkine's anti-cholera inoculations were so thoroughly tested in Calcutta was aided by Simpson's ready appreciation of this great discovery.

When Simpson was about to leave Calcutta, he received a letter from Ronald Ross enquiring about the post of Health Officer. Simpson advised Ross to wait until the advertisement appeared, enclosed a printed leaflet setting out the duties and salary, ${ }^{31}$ and followed this with a further letter and comment about the post: "I think you would

\footnotetext{
${ }^{27}$ Administration Report of the Commissioners of Calcutta for 1886/1887, Main Report, Part VII Sanitation, pp. 71-73, British Library, India Records V/24/2873.

28 'Health of Calcutta in 1888', Lancet, 1890, i: 46-47.

29 'Dr. W. J. R. Simpson', Ind. med. Gaz., 1897, 32: 383-384.

30 Ibid.

${ }^{31}$ Printed leaflet on Health Officership in Calcutta, Ross Archives 01/108. The salary was advertised as $£ 1,200$ rising to $£ 1,500$.
} 
like the appointment but under existing conditions I doubt if you would". 32 The salary at that time was $£ 1,200$ rising to $£ 1,500$, but, Simpson added, "The Engineer's salary is $£ 2,500$, why there should be this difference I fail to see". ${ }^{33}$ Much had been achieved in Simpson's time in Calcutta. He had worked hard, with some success, to improve the drainage of the town, the water supply, and the inadequate building regulations. A new drainage system for the town and suburbs was inaugurated in 1896 and a strong Building Commission had been appointed, before he resigned, to draw up a proper Building Act for Calcutta.

In 1894, at the Indian Medical Congress where Simpson was Secretary and organizer, he advocated a sanitary service for the civil population, consisting of administrative, investigative, and scientific branches which should form a major department in all large towns. The government of India approved the scheme in 1895, but delays meant that his ideas were not implemented. Simpson raised the matter again at the British Medical Association's meeting in Edinburgh in $1898,{ }^{34}$ commenting that the continued absence of trained staff and laboratories was a major handicap in the fight against plague. Cantlie affirmed "That the urgency for a sanitary service for India as suggested by Dr. Simpson was imperative". ${ }^{35}$ As late as 1912, Simpson's views were unchanged. "I still think there should be a Royal Commisson enquiring into the State of India as regards sanitation, malaria and plague." 36

In his presidential address before the Society of Tropical Medicine and Hygiene in $1919,{ }^{37}$ Simpson highlighted again the need for a specially trained and separate sanitary service, schools of hygiene and preventive medicine, sanitary engineering, and laboratories for research in India. "I am convinced that until a proper sanitary service for India is formed ... there will be no real progress and India will remain defenceless against epidemics . . .. Public Health should not be as it is in India a by-wash of the education department, in which it was placed as a sort of miscellaneous item along with archaeology ... in which the topsy-turvy doctrine is held that people must be educated before they can be protected against disease . . . the only education in sanitary matters the people understand is sanitary laws and bye-laws and this is the form education should take."38

Simpson left Calcutta with a reputation for "undaunted zeal and unwearied perseverance". 39 He later gave evidence to the Indian Plague Commission describing cases examined in $1896^{40}$ and made a contribution to the Sixth Report of the Royal Commission on Vaccination ${ }^{41}$ where experiences in Aberdeen and India were noted.

\footnotetext{
32 W. J. R. Simpson, letter to R. Ross, 27 May 1897, Ross Archives 01/098. The Ross Archives are held in the library of the London School of Hygiene and Tropical Medicine. See note 73 below.

33 W. J. R. Simpson, letter to R. Ross dated 14 August 1897, Ross Archives 01/107 File 1.

${ }^{34}$ Simpson's paper 'Plague in India' read at the BMA Tropical Diseases Section in Edinburgh was reported in the Lancet, 1898, ii: 450; and in the Br. med. J., 1898, ii: 368.

${ }^{35}$ Report of the BMA meeting in Edinburgh, Section on Tropical Diseases, Lancet, 1898, ii: 451.

36 W. J. R. Simpson, letter to R. Ross, undated [March 1912], Ross Archives 33/118 File 33.

${ }^{37}$ Simpson had been elected President following such eminent epidemiologists as Manson, Bruce, Ross, and Leishman.

${ }^{38}$ Simpson, op. cit., note 21 above, p. 822.

39 Farewell address, Ind. med. Gaz., 1897, 32: 387.

40 W.J. R. Simpson, Proceedings of the Indian Plague Commission, Minutes of Evidence III, London, HMSO, 1900 , pp. 368-379.

${ }^{41}$ W. J. R. Simpson, On vaccinia produced by passing the virus of small pox through the cow and calf, 1896, Parliamentary papers, XLVII, 661-686.
} 
Accounts of Simpson's work in India reveal a man well aware of Indian customs and the effects of other events like war in the continent. The frustrations of dealing with the numerous official bodies with an interest in environmental health and the financial limitations imposed must have been a burden and taken their toll.

One incident connected with India occurred in 1905, after Simpson had left the country, and shows how tenacious and single-minded he could be in supporting a colleague against the full authority of the Indian Government. An accident in a laboratory at Mulkowal involving the contamination of an anti-plague vaccine became known as the Haffkine affair. The Indian government blamed Professor Haffkine ${ }^{42}$ for nineteen deaths due to tetanus. Simpson, believing him innocent, claimed that Haffkine had been very badly treated by the Government. Ronald Ross, together with Simpson and eight other eminent pathologists and professors of hygiene, sent a letter to The Times ${ }^{43}$ showing conclusively that Haffkine could not have been involved. Simpson wrote to Ross: "Poor Haffkine, I fear the Government are determined to stand by the position they have taken up and they prefer to be guided by the unfair reports of the Indian Commission and the Lister Institute ... it is however a bad day for science when truth is dominated by passions and expediency." ${ }^{44}$ Largely due to the efforts of Ross and Simpson, Haffkine was later exonerated and offered another post in India, which he accepted.

In 1897, the Medical Board at King's College, London, appointed a committee to consider the general question of the teaching of hygiene and public health. ${ }^{45}$ The chair of hygiene, which had been instituted in 1869 , was advertised, and Simpson, who by then had returned from India and was forty-two years old, was elected by Council on 11 March $1898 .{ }^{46}$ The Hygiene Department included courses for medical officers of health, public analysts, sanitary inspectors, and plumbers. ${ }^{47}$ The duties of the Professor were to lecture on hygiene to medical and other students, to give the occasional demonstration, and to deliver an annual course of lectures on the laws of health to students in the Theological Department. ${ }^{48}$ It is clear from information in the King's College Archives that there was no salary attached to the chair of hygiene. Accounts for the years $1898-1903^{49}$ show small sums paid to Simpson from various departments and including evening classes. A total sum of twenty guineas had been paid in $1896 .{ }^{50}$

An interesting aspect of Simpson's work was his support for the hard-fought and controversial campaign to institute a course in household science, successfully started

\footnotetext{
${ }^{42}$ Waldemar Haffkine was born in Odessa, Russia, in 1860, and died in Switzerland in 1930. In 1884, he earned the degree of DSc. in zoology. He produced vaccines against plague and cholera which were widely used in India.

43 The Times, 29 July 1907 , letter dated 15 July 1907.

44 W. J. R. Simpson, letter to R. Ross, 9 June 1907, Ross Archives 28/063.

${ }^{45}$ King's College, London, Special Committees Book, Medical Committee meeting 26 March 1897, p. 14, King's College Archives.

${ }^{46}$ Letter from Waltcr Smith, Secretary of King's College, to W. J. Simpson dated 12 March 1898, King's College London, outletters book U-OLB20, King's College Archives.

47 F. J. C. Hearnshaw, Centenary history of King's College, London, 1828-1928, London, Harrap, 1929.

48 Professor of Hygiene - notice of the post, 1 December 1897, King's College Archives.

49 Information from A. J. B. Mussell, Archives Department, King's College, London, 9 October 1985.

${ }^{50}$ Ibid., 21 November 1985.
} 


\section{William John Ritchie Simpson (1855-1931)}

at King's College in 1908. Simpson's early views on health education and sanitary science were in sympathy with protagonists like Alice Ravenhill, a pioneer in what would now be called home economics. 51

Under the King's College, London, Transfer Act of 1908, the separation of King's College Hospital from the College took place by the removal of the former to a new site on Denmark Hill, Camberwell, in 1909. Simpson was transferred to King's College Hospital Medical School but continued to lecture to theological students at the College. The reconstitution of the Department of Hygiene and Public Health was proposed in 1910, ${ }^{52}$ with the appointment of more staff and additional laboratory facilities.

In 1911, Charing Cross Hospital Medical School transferred its science teaching to King's College. The rooms vacated were modified and on 31 October 1912, the laboratories were handed over to the University for the use of the Public Health and Bacteriology Departments. The professional and teaching staff were transferred from King's College Hospital Medical School to Charing Cross Hospital. The new laboratories in Chandos Street housed bacteriology on the upper floor and, on the floor below, the Public Health Department headed by Simpson. "The laboratory for chemical analysis, the adjacent rooms and the theatre, which leads off the main laboratory, are all admirably suited to the routine teaching of sanitary science ... and the apparatus and other equipment are entirely satisfactory."53

It was said of Simpson, in his new role of professor, that he had a "peculiar strident voice and a hesitant half-stammering manner and he ambled on in a style which was barely audible". 54 Philip Manson-Bahr described the content of Simpson's lectures as a "maze of drains, ditches, lavatories and houses" 55 and added that the subject was dreary. This is arguable, but this authoritative biographer concluded that Simpson was not only sincere in developing the new subject of tropical hygiene but "concealed beneath a benign exterior a will-power and great determination in enforcing his views". 56

High mortality rates amongst Europeans living in hot climates had been recognized for centuries. Malaria, yellow fever, trypanosomiasis, filariasis, schistosomiasis, and especially cholera and plague were the main killers. The unhealthiest British colonial area, the West African Gold Coast, illustrates the magnitude of the problem. In 1895, the number of European officials on the Gold Coast was 175, of which 17 died and 24 were invalided home within a year. ${ }^{57}$ The figures were similar in other West African Colonies.

51 C. E. J. Daniels and R. A. Bayliss, 'Alice Ravenhill, home economist 1859-1954', Westminster Studies in Education no. 8, 1985: 21-36.

52 King's College, London, Minutes of Delegacy - Minute Book 1, Delegacy meeting, 10 May 1910, p. 58, King's College Archives.

53 'Charing Cross Hospital Medical School and the university of London', Br. med. J., 1912, ii: 1323.

54 P. Manson-Bahr, History of the School of Tropical Medicine in London, 1899-1949, Memoir II, London

School of Hygiene and Tropical Medicine, London, H. K. Lewis, 1956, p. 136.

55 Ibid., p. 137.

56 Ibid.

${ }^{57}$ C. Bruce, The Broadstone of Empire-problems of Crown Colony administration I, London, Macmillan, 1910 , p. 403. 
At the turn of the century, the European powers began to realize that further exploitation, with the development of trade and investment, could be achieved only if tropical diseases were investigated and controlled. In addition, economic interests coincided with the success of the germ theory of disease. ${ }^{58}$ Tropical medicine thus emerged as a new discipline, the term being first used in $1897 .{ }^{59}$

The appointment of Joseph Chamberlain as Secretary of State for the Colonies in 1895 provided the initiative and encouragement for change. He invited the Royal Society to investigate tropical diseases and ensured the collection and publication of reliable annual records. The appointment of Patrick Manson ${ }^{60}$ as medical adviser to the Colonial Office in 1897 was a major catalyst. Manson believed that the difficulties encountered with tropical diseases were due to parasitism and not climate, and that with greater knowledge, through research, tropical diseases would be eliminated or controlled. "He now firmly believed in the possibility of tropical colonization by the white races . . . heat and moisture were not in themselves the direct cause of any important tropical disease. The direct causes of $99 \%$ of these diseases were germs .... To kill them was simply a matter of knowledge and the application of this knowledge-sanitary science." $" 61$

Tropical medicine made considerable progress in 1898. In that year the Journal of Tropical Medicine was launched, a new section on tropical diseases was created at the annual meeting of the British Medical Association in Edinburgh, and moves to establish two special schools for teaching and research in tropical medicine were carried forward in England. Ross's famous work on the relation between mosquitoes and malaria was also published.

The new journal was edited by James Cantlie ${ }^{62}$ and Simpson. Cantlie, a fellow Scot, had graduated from Aberdeen three years before Simpson and subsequently, like him, became a specialist in tropical diseases. Both had early experiences in hot climates, Simpson in Egypt in 1883 during an epidemic of cholera, and Cantlie in Hong Kong. The first volume of the Journal, in August 1898, was to "supply a want which had long existed [and] devoted to the publication of papers on tropical diseases and to the discussion of subjects scientific and practical, affecting the interests of medical men in tropical and sub tropical countries." ${ }^{\circ 3}$ It was meant to appeal especially to medical officers in the many military and colonial services as well as to medical missionaries. Of the early articles, only two out of a total of nearly two hundred were devoted to sanitation and public health, by far the majority being clinical studies concerned with

\footnotetext{
${ }^{58} \mathrm{M}$. Worboys, 'The emergence and early development of parasitology', in K. S. Warren and J. Z. Bowers (editors), Parasitology - a global perspective, New York, Springer, 1983. p. 7.

${ }^{59} \mathrm{M}$. Worboys, 'The emergence of tropical medicine: a studyin theestablishment of a scientificspeciality', in G. Lemaine, R. MacLeod, M. Mulkay, and P. Weingart (editors), Perspectives on the emergence of scientific disciplines, The Hague, Mouton, 1976, pp. 75-98.

60 Patrick Manson (1844-1922) studied medicine at Aberdeen, spent twenty-two years abroad including periods in China and Hong Kong, demonstrated the transmission of the nematode Wuchereria bancrofti by Culicine mosquitoes, and is often referred to as the father of tropical medicine and parasitology.

${ }^{61} \mathrm{P}$. Manson, 'The possibility of acclimatisation of Europeans in tropical countries', Br. med. J., 1898, i: 1167-1169.

${ }^{62}$ See J. C. Stewart, The quality of mercy. The lives of Sir James and Lady Cantlie, London, Allen \& Unwin, 1983.

${ }^{63}$ J. trop. Med., 1898, 1 : 1.
} 
specific diseases. After four years, Manson wanted to take over control of the Journal, but Cantlie's wife and friends were opposed. Simpson, feeling that Cantlie should have the credit for the work, suggested removing his own name as co-editor but Cantlie would not hear of it. ${ }^{64}$

The inaugural meeting of the tropical diseases section of the British Medical Association at Edinburgh in $1898^{65}$ was attended by medical men from thirteen countries and colonies. Manson delivered the introductory address ${ }^{66}$ and Simpson, one of the vice-presidents, spoke on 'Plague in India'. Manson saw three distinct functions for the new section-to work for the affiliation and organization of the 5,000-6,000 British practitioners interested in tropical medicine, to insist on improved education in tropical medicine, and to discuss the problems of tropical diseases.

It was at this conference that some of Ross's investigations and latest discoveries concerning the role of mosquitoes in the transmission of malaria were announced. In 1921 Simpson recalled the occasion in a letter to Ross, who by then was writing his memoirs. "I remember the profound sensation produced among the members when Sir Patrick read out a telegram he had received from you describing your success in conveying Malaria from bird to bird by means of 'grey' mosquitoes fed on malaria infected birds. At the same meeting was shown microscopical specimens which you had sent him demonstrating the progressive development of the malarial parasite in the mosquito. A resolution was unanimously passed sending you the members' congratulations on your great and epoch making discovery." 67

In a series of lectures at St George's Hospital in 1897, Manson proposed a plan to bring about the inclusion of tropical medicine into the medical curriculum. ${ }^{68} \mathrm{He}$ was supported by Cantlie and Simpson, and "The opening of the London School signified the establishment of Tropical Medicine as a speciality for teaching, professional practice and research". ${ }^{69}$ Chamberlain was also involved in these developments in medical education. Early in 1898, he submitted to the War Office, the Admiralty, the India Office, and the Foreign Office the draft of a circular which was issued in its final form on 11 March, urging the desirability of extending the teaching of tropical medicine in this country and enclosing a copy of Patrick Manson's earlier address. The question was considered at King's College, where Simpson was Professor of Hygiene, and he was asked to consider "what arrangements could be made for a postgraduate course on the subject". ${ }^{70}$

By October 1899, two schools of tropical medicine were in operation, one in London and the other in Liverpool. Manson, who became head of the London School, wanted to combine a teaching hospital with research work into parasitological aspects of disease. Parasitology thus emerged as a discipline "to provide the zoological

\footnotetext{
${ }^{64}$ Stewart, op. cit., note 62 above, p. 128.

${ }^{65} \mathrm{Br}$. med. J., 1898, ii: 323.

66 J. trop. Med., 1898, 1: 22-25.

${ }^{67}$ R. Ross, Memoirs with a full account of the great malaria problem and its solution, London, Murray, 1923, p. 306.

${ }^{68} \mathrm{P}$. Manson, 'The necessity for special education in tropical medicine', Lancet, 1897, ii: 842-845.

69 Worboys, op. cit., note 59 above, p. 87.

${ }^{70}$ Letter from Walter Smith, Secretary to Professor W. J. R. Simpson, dated 26 October 1898 - Tropical Medicine, Outletter Books, OLB 20/21, King's College Archives.
} 
underpinning for Tropical Medicine", ${ }^{71}$ Ross was appointed lecturer and later Professor at Liverpool. Having earlier been friends and co-workers, Manson and Ross drifted apart and had radically different philosophies of health. ${ }^{72}$ Ross's approach was preventive and progressive and, like Simpson, he was an advocate of public health, practical sanitation, and vector control. The sanitary measures Ross was keen to introduce are reminiscent of the methods Simpson was calling for in the 1890 s and in London twenty years later. They became close friends, and Simpson was a supporter of Ross in a number of later events. ${ }^{73}$ Chamberlain, advised by Manson, refused to accept Ross's scheme for improvements in the sanitation in West Africa in 1901. Ross's comment in his memoirs indicates some of the bitterness felt. "Chamberlain has done some good (and won much political capital) by suggesting the schools of tropical medicine but in my opinion, his refusal of a proper sanitary organisation for the colonies largely cancelled, then and since, the benefits which might have accrued."74

Arguments about priority for the discovery of the various tropical diseases and competition between the Liverpool and London schools were commonplace in the early part of the twentieth century. The London School had psychological and financial backing from the Colonial Office which was denied the Liverpool School in its first few years. Simpson, as joint editor of the Journal of Tropical Medicine and co-founder of the London School, ${ }^{75}$ became involved in these squabbles. Ross maintained that Manson had claimed that the Royal Society Sleeping Sickness Commission had been sent out "under the auspices of the London School of Tropical Medicine". 76 David Bruce attacked Manson in strong language, and Ross, who blamed Manson for the friction, wrote to Cantlie, the joint editor of the journal. "In fact, everyone considers that you and Simpson as editors of the J.T.M., and also members of the London School, have together with Sir Patrick Manson, been doing some unjustifiable advertising of your school in this connection . . . an impression which should be removed as early and as publicly as possible."77 Simpson replied suggesting that Ross should drop the subject, which, according to Simpson, was "unimportant and of no special interest". ${ }^{78}$

Among the books that Simpson wrote was a small manual, written at the request of the committee of the London School, dealing with personal hygiene in a simple and popular manner "useful for those residing in or visiting the tropics". ${ }^{79}$ A treatise on plague, dealing with the historical, epidemiological, clinical, therapeutic, and preventive aspects of the disease, was published in 1905. In the previous year, over $1,000,000$ had died from plague in India alone. His preface referred to a recurring

${ }^{71}$ Worboys, op. cit., note 58 above, p. 15.

72 Worboys, op. cit., note 59 above, pp. 75-98.

${ }^{73}$ See the Ross Archives catalogue, Author Index (W. J. R. Simpson) second half, March 1912-July 1980, compiled by Mary E. Gibson held at the London School of Hygiene and Tropical Medicine Library.

74 Ross, op. cit., note 67 above, pp. 436-437.

${ }^{75}$ Manson-Bahr, op. cit., note 54 above, p. 136.

76 J. trop. Med., 1902, 5: 158.

77 R. Ross, letter to Editor (Dr Cantlie) of the Journal of Tropical Medicine, 10 November 1905, Ross Archives 33/036.

${ }_{78}$ W. J. R. Simpson, letter to R. Ross, 30 November 1905, Ross Archives 33/037.

${ }^{79}$ W. J. R. Simpson, The maintenance of health in the Tropics, 2nd ed., London, John Bale, Sons \& Danielsson, 1916. 
theme in his writings: "It seems to have been considered a waste of money to spend 20,000 or 30,000 pounds in studying the disease and its prevention, though twice or three times that amount is but a small fraction of the vast sums spent for the most part uselessly on administrative and executive methods." 80

He returned to the topic of plague in his Croonian lectures delivered before the Royal College of Physicians in 1907. ${ }^{81}$ The theme of the last lecture was a familiar one, the necessity for the formation of a special and trained plague service for the prevention and mitigation of plague in India.

During the first thirty years of the present century, in a succession of important appointments in the colonies, Simpson acted as adviser, commissioner, and consultant, becoming an established authority on tropical hygiene. "His reputation as a solid expert gave him freedom to report the facts as he saw them". ${ }^{82} \mathrm{He}$ visited Hong Kong, Singapore, and Africa, in particular the West African colonies, East Africa including Zanzibar, Northern Rhodesia and South Africa. For example, in a lecture to the South African branch of the BMA in 1901, Simpson was quick to point out the insanitary conditions of Cape Town and the remedies required, "Demolition and reconstruction on sanitary principles ... house building has not been regulated in order to secure a sufficienty of air space, ventilation or the requirements of a healthy house but to secure as many houses on as limited a space as possible." ${ }^{.83}$ His experience was unrivalled, and Sir Malcolm Watson described him as "the most distinguished tropical sanitarian in the British Empire."84

A series of reports resulted, on cholera in Calcutta (1894); ${ }^{85}$ plague in the Gold Coast $\left(1909,{ }^{86} 1925^{87}\right)$; sanitary matters in various West African colonies $(1909)^{88}$ and in East Africa (1915); ${ }^{89}$ and sanitary matters among the mines and mining villages of the Gold Coast (1925).$^{90}$ Simpson's reports are very detailed, thorough accounts showing the strenuous efforts he made to effect change. Frequently critical of the arrangements existing at the time, he was not willing to blame the medical staff. The difficulties, he believed, were more of a financial and political nature. Two examples from these reports illustrate the work accomplished and the recommendations made.

${ }^{80}$ W. J. R. Simpson, A treatise on plague, Cambridge University Press, 1905, preface p. xii.

${ }^{81}$ W. J. R. Simpson, Croonian Lectures on Plague, reprinted in the Lancet, 1907, i: 1757-1761; ii: 73-78, 142-147, 207-212.

${ }^{82}$ A. Beck, A history of the British medical administration of East Africa 1900-1950, Cambridge, Mass., Harvard University Press, 1970, p. 50.

${ }^{83}$ W. J. R. Simpson, lecture on plague delivered in Cape Town, 31 May 1901, and reprinted in the Cape Times, Cape Town, 15 June 1901.

${ }^{84}$ M. Watson, The battle for health in Central Africa, London, J. Murray, 1953, p. 7.

${ }^{85} \mathrm{~W}$. J. R. Simpson, Cholera in Calcutta in 1894 and anti-choleraic inoculation, reprinted from Health Officers' Annual Report on the Health of Calcutta, 1894.

${ }^{86}$ W. J. R. Simpson, Report on plague in the Gold Coast in 1908, London, J. \& A. Churchill, 1909.

87 W.J. R. Simpson, Gold Coast-Report to the Secretary of Statefor the Colonies on the outbreak of plague in the Gold Coast Colony and Ashanti, London, Crown Agents for the Colonies, 1925.

${ }^{88}$ W. J. R. Simpson, Sanitary matters in various West African colonies and the outbreak of plague in the Gold Coast, Cd. 4718, London, HMSO, 1909.

89 W. J. R. Simpson, Report on sanitary matters in the East Africa Protectorate, Uganda and Zanzibar, London, Colonial Office, 1915, Africa, No. 1025.

${ }^{90}$ W. J. R. Simpson, Report to the Secretary of State for the Colonies on the sanitary conditions of the mines and mining villages in the Gold Coast and Ashanti, London, Crown Agents for the Colonies, 1925. 


\section{R. A. Baker and R. A. Bayliss}

Simpson visited the Gold Coast in 1908 to take control of the arrangements for combating bubonic plague. A laboratory for diagnostic purposes was established in Accra, people were inoculated, land cordoned off, and quarantine arrangements established. 300 fatal cases were reported after the first outbreak in January 1908, and, although later outbreaks did occur, Simpson was able to declare the colony free of plague by May of the same year. The report, published in 1909, contained photographs, plans, maps, and meteorological statistics.

The report on the mines and mining villages of the Gold Coast of 1925 recommended the appointment of Provincial Health Officers who would visit and inspect the towns and give advice. The high death rates in the goldmines was due to a number of factors but chiefly to conditions favouring the prevalence of ancylostomiasis. The recommendations included the recruitment of healthy men for the mines, treatment of people infected with the hookworm Ancylostoma, destruction of rats to prevent the spread of plague, and the provision of adequate medical arrangements including an auxiliary West African medical service, locally trained.

The problems of recruiting suitable doctors and other qualified medical staff to serve in tropical Africa, especially West Africa, known for many years as the "White Man's Grave", were highlighted by Simpson's report for the Colonial Office on Sanitary matters in various West African colonies. It was clear that the organization and equipment existing in 1908 was still "totally ineffective from the point of view of public health and preventive medicine generally", ${ }^{91}$ and his report included suggestions for the re-organization and improvement of the health service "if it is to become attractive and popular and to compete with all other government services such as the Indian Medical Service or the Naval Medical Service or the Royal Army Medical Corps."92

Simpson was appointed a member of the Advisory Medical and Sanitary Commitee for Tropical Africa in 1909, which later became the Colonial Advisory Medical and Sanitary Committee. He was often impatient at the way business was conducted in committee, commenting to Ross, on the Annual Reports of the Gold Coast: "In the sanitary report in the section dealing with 18 towns the whole matter was finished in about 10 minutes. As a practical sanitarian I am concerned that this way with the Gold Coast and it is the same with all the African reports is nothing less than a farce." 93

Simpson believed that many of the inadequacies in tropical hygiene and sanitation were due to lack of finance, which could be overcome not through medicine but through reform in other ways. A liberal budget, he said, was the prerequisite for a new policy of sanitation, but as Beck expressed it: "Claims of sanitation and public health could not receive the attention they deserved because they possessed the disadvantage of being considered unproductive and necessarily adding to the monetary embarrassment endemic in the protectorates." 94

Simpson was involved in the First World War as Principal Medical Officer for the Serbian Relief Fund. He worked mainly in the Monastir area and apart from medical aid was involved in providing food and clothing for refugees. The toll of illness in the

${ }^{91}$ Simpson, op. cit., note 88 above, p. 554.

92 Ibid., p. 574.

${ }_{93}$ W. J. R. Simpson, letter to R. Ross, 13 January 1912, Ross Archives 27/086.

${ }^{94}$ Beck, op. cit., note 82 above, pp. 26-27. 
Balkans had been great, with nearly 100,000 troops evacuated from Gallipoli with sickness in less than seven months. His eight-months' stay, until early in 1918, was described in a paper to the Society of Tropical Medicine and Hygiene. Simpson described the work of the French anti-malarial commision, and the anti-mosquito protective clothing, invented by his wife, was shown.

In a discussion of two papers at the Royal Society of Tropical Medicine and Hygiene's meeting, Simpson commented on the need for an improved sanitary branch in the army. "In the next war-for I am not one of those who believe that war is going to disappear from the face of the globe - there will be a sanitary organisation ready, which will as soon as war breaks out, send its Chief Health Officers and staff, with material and powers of administration, to go forward and work in conjunction with the other military staff officers. I am sure that in this way we shall have a much healthier army and no repetition of the Gallipoli or Mesopotamia disasters."95

Housing and town planning remained a consuming interest until very late in his life. He had acquired considerable practical experience of this earlier in his career in Aberdeen, Calcutta, Africa, and Singapore. Jamaica was a place he wanted to visit "to put the authorities there on the right lines of rebuilding Jamaica" 96 but the West Indies was one of the few British territories he never visited. "Everywhere I have found that Town Planning without strict and effective building laws has been a failure ... it was the same in Calcutta where it took me 10 years before suceeding to secure effective building laws." 97

The last chapter of his life was spent as Director of Tropical Hygiene at the Ross Institute, a research institute as well as a hospital for tropical diseases, opened in July 1926 in Putney, London. His role in helping to establish the Institute was later acknowledged by both Ross and Aldo Castellani. By now Simpson was seventy, and was working closely with Ross, the Director-in-Chief. Simpson died at the Institute on 20 September 1931.

One obituarist described him as a man "though of a kindly disposition he was possessed of great determination, which in certain circumstances brought him into conflict with those with whom he had to deal". 98 Another wrote of "Devotion to the practical application of hygiene necessarily left him little time for 'research' as understood in the present day". 99 A third writer ${ }^{100}$ perhaps summed up his character best as a "Genial and kindly man, though a strong one when occasion required"; and Watson's use of the phrase "core of native granite" reflects Simpson's strength of will. ${ }^{101}$

Simpson's career must be seen against the background of increasing opportunities for medical men in late-nineteenth-century Britain, including the "prodigious

\footnotetext{
${ }^{95}$ W. J. R. Simpson, 'The sanitary aspects of warfare in South-Eastern Europe', Trans. R. Soc. Trop. Med. Hyg., 1919, 12: 1-10. Simpson's son, Frank, serving in the Royal Flying Corps, was killed in 1917; see obituary, 'Captain F. W. H. Simpson', Br. med. J., 1917, I: 308.

${ }_{96}^{6}$ W. J. R. Simpson, letter to R. Ross, 15 August 1907, Ross Archives 28/103.

${ }^{97}$ W. J. R. Simpson, letter to Rt. Hon. Arthur Greenwood, MP, 22 April 1931, Archives, Royal College of Physicians of London.

${ }_{98}$ C. C. Low, 'Obituary W. J. R. Simpson', Br. med. J., 1931, ii: 633.

99 W. G. King, 'W. J. R. Simpson', ibid., 1931, ii: 682.

100 R. T. Hewlett, 'W. J. R. Simpson', Nature, 1931, 128: 695-696.

101 Watson, op. cit., note 1 above, p. 813.
} 
growth" 102 of paid employment both in the public and private sectors. Unfortunately, little is known of Simpson's early life and nothing about the decision to enter on medical studies. The years between graduation with good, if not outstanding degrees, and his appointment in Aberdeen in 1881 may be considered characteristic of the times, when a succession of salaried and sometimes residential posts often provided a useful experience for a man deciding upon the direction of a medical career. The problem of salary issues, of lay control and controversy over the nature and scope of the post were found in Aberdeen as elsewhere. Wohl has rightly concluded that men of high calibre were often found in Public Health, and sometimes people of "outstanding quality". ${ }^{103}$ Simpson might well have gone on to more senior posts in central and local government like an Aberdeen successor, Theodore Thomson. ${ }^{104}$

The decision to move to India could be explained by the better-paid opportunities and the challenge and scope presented by a city in which major sanitation problems were abundant. The adventure of life abroad was well known. India had a long tradition of attracting medical men, and Simpson had already experienced a very brief taste of the problems of cholera in Egypt. ${ }^{105}$

The chair of hygiene at King's College London was hardly a financial attraction, and a number of staff were opposed to the chair on the grounds of expense and the duplication of resources. There were also the problems of student numbers. ${ }^{106}$ The opportunities of a senior university post were, however, grasped by Simpson, and the long career of consultancy developed at an exciting time when, in the words of Williams, the "whole subject appeared to burst into flame". ${ }^{107}$ Other contemporaries had similarly wide experience at home and abroad. David Bruce ${ }^{108}$ worked in banking, moved from zoological studies to medicine, and from private practice into the army. Patrick Manson ${ }^{109}$ was initially an engineering apprentice; enforced convalescence led to scientific studies, then to a medical course, and a brief period in an asylum before "an adventurous spirit found an opening". ${ }^{110}$ Ronald Ross, ${ }^{111}$ born in India, combined medical studies with many other interests and was for a time a ship's surgeon. Malcolm Watson ${ }^{112}$ obtained a DPH and also went to sea before public medical service in Malaya.

A medical family background could be a strong factor in determining such a career, but chance, illness, curiosity, and a somewhat casual interest in science, health, or

\footnotetext{
102 M. J. Peterson, The medical profession in mid-Victorian London, Berkeley and Los Angeles, University of California Press, 1978, P. 110.

${ }^{103}$ A. S. Wohl, Endangered lives: public health in Victorian Britain, London, Dent, 1983, pp. 192-193.

104 [Anon.], 'Theodore Thomson', Lancet, 1916, i: 647-648.

105 W. J. R. Simpson, Somenotes on the cholera at Damietta, Parliamentary Papers 1884, LXXXIII: 439-449.

${ }^{106}$ Hearnshaw, op. cit., note 47 above, ch. 10.

${ }^{107}$ P. O. Williams, 'The scientific neglect of tropical medicine', in C. Wood (editor), Tropical medicine from romance to reality, London, Academic Press, 1978, p. 16.

${ }^{108}$ H.H. Scott, A history of tropical medicine, London, Edward Arnold, 1939, vol. 2, pp. 1018-1021.

109 Ibid., pp. 1068-1076.

${ }^{110}$ P. H. Manson-Bahr and A. Alcock, The life and work of Sir Patrick Manson, London, Cassell, 1927, p. 5.

${ }_{111}$ Scott, op. cit., note 108 above, pp. 1086-1090.

112 J. Field, 'Sir Malcolm Watson', DNB 1951-1960, London, Oxford University Press, 1971, pp. 1023-1025.
} 
disease might also be decisive. ${ }^{113}$ No set pattern emerges. Simpson moved forward in a systematic way, took opportunities as they came, establishing himself quickly in the developing area of tropical medicine when scientists were beginning to understand what caused, cured, and prevented many of the intractable tropical diseases. He was an impatient, determined, practical man who wanted to see rapid change. His speciality was in an area where great strides were being made during his working life. In tropical countries, the magnitude of the work and problems were immense and it was recognized that "the strenuous efforts he made in the direction of reforms effected a considerable change." ${ }^{114}$ His early work and achievement in Scotland and later in India and the African colonies and the role he played in establishing medical services and sanitary organization, in opening up the tropics to Europeans, and improving the health of colonial people placed him in the "front rank of sanitarians". ${ }^{115}$ Although he produced little written work of long-standing significance, his treatise on plague was an important publication, described as "an interesting, well written and valuable monograph". ${ }^{116} \mathrm{He}$ emerges overall as a notable pioneer yet second-rank figure in the history of tropical medicine and hygiene.

He attained public success and recognition, including a knighthood, a strong position in medical publishing, and a high reputation in public health and hygiene. That his work has often been ignored may be partly explained by the many other talented and sometimes controversial figures who were more prominent in tropical medicine at this time.

\section{ACKNOWLEDGEMENTS}

We wish to acknowledge help from librarians and archivists in Aberdeen, Huddersfield, Jersey, Leeds, the London School of Hygiene and Tropical Medicine, the Royal College of Physicians, King's College, London, the British Library India Records, Library of the Wellcome Institute for the History of Medicine.

113 Peterson, op. cit., note 102 above, p. 44.

${ }_{114}$ A. Balfour and H. H. Scott, Health problems of the Empire-past, present and future, London, Collins, 1924, vol. 5. p. 82.

115 Watson, op. cit., note 1 above, p. 813.

116 The Times, 22 September 1931. 